\title{
Perception, Determinants and Barriers for the Adoption of Climate Change Adaptation Options among Nepalese Rice Farmers
}

\author{
Niranjan Devkota1 ${ }^{*}$, Ram Kumar Phuyal'2, Durga Lal Shrestha1 \\ ${ }^{1}$ Tribhuvan University, Kathmandu, Nepal \\ ${ }^{2}$ Center for Economic Development and Administration, Tribhuvan University, Kathmandu, Nepal \\ Email:*niranjandevkota@gmail.com
}

How to cite this paper: Devkota, N., Phuyal, R.K. and Shrestha, D.L. (2018) Perception, Determinants and Barriers for the Adoption of Climate Change Adaptation Options among Nepalese Rice Farmers. Agricultural Sciences, 9, 272-298. https://doi.org/10.4236/as.2018.93021

Received: January 31, 2018

Accepted: March 17, 2018

Published: March 20, 2018

Copyright $\odot 2018$ by authors and Scientific Research Publishing Inc. This work is licensed under the Creative Commons Attribution International License (CC BY 4.0).

http://creativecommons.org/licenses/by/4.0/

\begin{abstract}
This paper estimates the perceptions, determinants and barriers regarding the adoption of climate change adaptation options among Nepalese rice farmers. A multi-stage sampling technique was used to source respondents for the study, and structured questionnaire techniques were used to collect data from 773 households across seven districts ( 3 from Terai and 4 from the hilly region of Nepal). A binomial logistic regression model was used to detangle the determinants for the adoption of climate change adaptation options among farmers. The results revealed that approximately $80.7 \%$ of the farmers perceived change in temperature, and $90 \%$ believed that there was a decrease in rainfall in the 30 -year period. In total, $77 \%$ of farming households responded that rice production and yield has decreased due to such changes, which has forced them to adopt available adaptation options. This study found that 12 adaptation options have been mainly used by rice farmers, and among them, there has been an increasing use of chemical fertilizer, climate-smart rice verities, and changes in nursery date, which are the first three adoption options. Overall, $71 \%$ of farmers adopt such adaptation options to protect themselves from perceived risk. However, farmers are facing several barriers, such as capital inadequacy, high cost of agricultural inputs, poor adaptation information provided to farmers, inadequate access to credit facilities and inadequate awareness about adaptation regarding the adoption of such options. Binomial regression results revealed that several factors influence a farmer's choice in adaptation measures. Our findings suggest the need for greater investment to remove these barriers and institutional shortcomings and help to improve a rice farmer's wellbeing.
\end{abstract}

\section{Keywords}

Climate Change, Barrier to Adopt, Rural Rice Farmers, Logit Model, Nepal 


\section{Introduction}

The concept of climate change adaptation has recently been popularized, as climate scientists and the IPCC have predicted that the global temperature will rise by $4^{\circ} \mathrm{C}$ in 2100 , and for such a situation, mitigation efforts will not work among both developed and developing countries, unless these efforts are widely accepted from the lowest policy level [1] [2]. Under these uncertainties, society knows enough to build possible scenarios on which to base decision making in both developed and developing countries [3]. However, farmers and policy makers in developing countries are further encouraged to adapt to climate change over time, since they are unable to mitigate climate change due to many socio-economic and institutional shortcomings [4]. Adaptation in agriculture, along with rice production, has been presented for a very long time, but a lack of proper adaptation practices based on weather variability and a changing climate is still a common problem in developing countries, including Nepal [5].

Rice is the primary food staple; it is the most important staple crops in South Asia and ranks first in Nepal in terms of production and livelihood [6] [7]. It is cultivated at an altitude from $300 \mathrm{~m}$ above sea level in the Terai plain to $3000 \mathrm{~m}$ above sea level in the Jumla valley in Nepal [8] [9]. Rice can be cultivated in irrigated and rainfed lowlands and uplands [10]. Rainfed rice covers $79 \%$ of rice areas, and $21 \%$ of rice areas are fully or partially irrigated [9] [11]. It accounts for $42.54 \%$ of the total area and $52.50 \%$ of total food grain production, provides employment for $70 \%$ of the population and contributes to $33.5 \%$ of the total GDP and $20 \%$ of the agricultural GDP. Further, rainfed rice also meets more than $50 \%$ of the total caloric requirement of Nepalese people, with an annual calorie per capita consumption of approximately $100 \mathrm{~kg}$ of milled rice [7] [9] [11]. The national average yield of rice production is $3171 \mathrm{t} / \mathrm{ha}$, greater than the national average yield of cereal products (2570 t/ha) [12]. From the consumption side, rice consumption in Nepal is $79.9 \mathrm{~kg}$ of milled rice per person per year [6]. Hence, poor rice crop prompts farmers to grow other cereal crops for food security [13].

[14] reported that rice production will double in South Asia by 2020. Furthermore, the IPCC has shown that every $1^{\circ} \mathrm{C}$ increase in temperature will lead to a $10 \%$ decline in rice yields. Similarly, [15] stated that Nepal has already faced the adverse effects of climate change on rice production in the Terai region. The average temperature during rice production has already crossed the threshold level and increased further. Even the rate of rice production for the last two decades was $1.4 \%$ per year, which was less than required. Likewise, rice areas have seen production decline from east to west due to large variations in rainfall and socioeconomic conditions [16]. These consequences have affected 37 districts of Nepal, mostly hills and mountainous regions; approximately 70 percent of subsistence rice producers have already faced food deficits, and further food shortage will create problems in malnutrition, starvation and inflation [15] [17]. 
[18] remarked that the extent of the impact of climate change on agriculture in Nepal has been affected partly by the nature of climate change and partly by adaptation practice dependency, as well as the ability for society to innovate technologies to mitigate climate. Agro-scientists have developed crop varieties that are resistant to erratic climate, such as drought tolerant, cold tolerant and submergence tolerant varieties, but the size of the required resources is likely to be well beyond their adaptive capacity [19].

From this approach, adaptations for rice production in Nepal can undergo many behavioral changes that can act to minimize harm or maximize gains from weather variability and climate change, such as in households, firms or governments [20]. These efficient adaptations help to maximize net benefits [20] [21]. Therefore, better adaptation knowledge and perceptions regarding new adaptation options should be well known. It is obvious that every adaptation is not advantageous for farmers [22], but knowing whether farmers have certain qualities, such as education, knowledge and other qualities, can encourage them towards better adaptation and coping strategies. Many determinant factors play a key role in climate change adaptation, and whether farmers are likely to adapt new technologies depends upon where the adaptation is done.

In Nepal, numerous studies have been performed on the effects of climate change on agriculture [8] [13] [22] [23] [24] [25], rice production [15] [16] [26] and climate change adaptation [24] [27] [28] [29] [30] [31]. Despite the interest in climate change adaptations at the local and regional levels, little literature is available on issues such as determinants, perceptions and barriers that affect the adoption of climate change adaptation options for rice production. Therefore, this study aims to fulfill this research gap.

The remaining part of this paper is organized into three sections. The next section will represent the overall methodology of the study, where materials and methods will be discussed. Then, the results and the discussion of key issues will be presented, followed by concluding remarks.

\section{Materials and Methods}

\subsection{Theoretical Framework}

Different choices are associated with different levels of utility [32]. Therefore, individual households generally reflect their preferences for different coping strategies based on their understanding. However, [33] and [34] opined that the decision regarding whether or not to adopt any adaptation options is considered to be under the general framework of utility and profit maximization. Furthermore, it is assumed that a rational farmer uses adaptation methods only when the net benefit from using such a method is significantly greater than the cost of not doing so [20]. Although the benefit is not directly observed, the action of economic agents is observed through the choices they make [33]. Suppose that $Y_{j}$ and $Y_{k}$ represent a household's benefit for two choices, which are denoted 
by $U_{j}$ and $U_{k}$, respectively.

The linear regression model could then be specified as:

$$
U_{j}=\beta_{j}^{\prime} X_{i}+\varepsilon_{j} \text { and } U_{k}=\beta_{k}^{\prime} X_{i}+\varepsilon_{k}
$$

In the case of the adaptation method, if a household decides to use option $j$, it follows that the perceived benefit from option $j$ is greater than the benefit from other options (i.e., $k$ ) which is depicted as:

$$
U_{i j}\left(\beta_{j}^{\prime} X_{i}+\varepsilon_{j}\right)>U_{i k}\left(\beta_{k}^{\prime} X_{i}+\varepsilon_{k}\right), k \neq j
$$

where $U_{i j}$ and $U_{i k}$ are the perceived benefits for adaptation options $j$ and $k$, respectively, by farmer $i, X_{i}$ is the vector of explanatory variables that influences the choice of the adaptation options, $\beta_{j}$ and $\beta_{k}$ are the parameters to be estimated, and $\varepsilon_{j}$ and $\varepsilon_{k}$ are the error terms assumed to be independently and identically distributed [27] [33].

The probability that a household will use method $j$ from the set of climate change adaptation options could then be defined as follows

$$
\begin{aligned}
P(Y=1 / X) & =P\left(U_{i j}>U_{i k} / X\right) \\
& =P\left(\beta_{J}^{\prime} X_{i}+\varepsilon_{j}-\beta_{k}^{\prime} X_{i}-\varepsilon_{k}>0 / X\right) \\
& =P\left(\left(\beta_{J}^{\prime}-\beta_{k}^{\prime}\right) X_{i}+\varepsilon_{j}-\varepsilon_{k}>0 / X\right) \\
& =P\left(\beta^{*} X_{i}+\varepsilon^{*}>0 / X\right)=F\left(\beta^{*} X_{i}\right)
\end{aligned}
$$

where $P$ is the probability function, $U_{i j}, U_{i k}$ and $X_{i}$ are as defined above, $\varepsilon^{*}=\varepsilon_{j}-\varepsilon_{k}$ is the random disturbance term, $\beta^{*}=\beta_{j}^{\prime}-\beta_{k}^{\prime}$ is the vector of unknown parameters that can be interpreted as the net influence of the vector of explanatory variables that influences adaptation, and $F\left(\beta^{*} X_{i}\right)$ is the cumulative distribution function of $\varepsilon^{*}$ evaluated at $\beta^{*} X_{i}$. The exact distribution of $F$ depends on the distribution of the random disturbance term, $\varepsilon^{*}$ [33] [34].

Depending on the assumed distribution that the random disturbance term follows, several qualitative choice models, such as linear probability, logit or probit models, can be estimated [32] [33] [34]. The logit and probit models are the most common models used in the literature, as such models have desirable statistical properties with probability values ranging and bound within 0 and 1 [34].

\subsection{Econometric Specification of the Model}

As discussed above, researchers have generally estimated the general framework of utility and profit maximization when measuring perception and determinants. To measure this estimation, recent studies in South Asia have been conducted [35] [36]. Following previous studies, a logit regression model was selected to identify the significant variable that determines whether or not youth rural rice farmers are adopting available adaptation options.

Suppose $Y$ is the available adaptation option to the farmer, which is a random variable, and $\mathrm{X}$ represents socioeconomic, institutional, social and other factors. 
For such a dichotomous outcome, the inferential statistical analysis used in this study is a logit model [36] [37]. The effect of $\mathrm{X}$ on the response probabilities, $P(y=j / x)$, can be estimated using a binary logit model, which is expressed as

$$
\begin{gathered}
P\left(Y_{i} / X\right)=F\left(Z_{j}\right)=\frac{\mathrm{e}^{Z_{i}}}{1+\mathrm{e}^{Z_{i}}}=\frac{1}{1+\mathrm{e}^{-Z_{i}}} \\
P\left(Y_{i}=J / X_{i}\right)=F\left(Z_{j}\right)=\frac{\mathrm{e}^{Z_{i}}}{1+\mathrm{e}^{Z_{i}}}=\frac{1}{1+\mathrm{e}^{-Z_{i}}} \\
Z_{i}=\beta_{0}+\beta_{1} X_{1 i}+\cdots+\beta_{n} X_{n i}+\mu_{i}
\end{gathered}
$$

The logit regression equation that is used to ascertain variables influencing determinants and perception when adopting adaptation options available to farmers is

$$
Y=\beta_{0}+\beta_{1} x_{1}+\beta_{2} x_{2}+\beta_{3} x_{3}+\beta_{4} x_{4}+\cdots+\beta_{25} x_{25}+\mu_{0}
$$

The choice of explanatory (independent) variables used in this study is based on data availability and a review of the literature [35]. From the numerous studies that have been performed to measure a farmer's perception, determinants and barriers, it has been found that determinants and perception are heavily influenced by socio-economic, institutional and social factors [13] [33] [34] [36] [38] [39].

Socio-economic characteristics include age, education, gender, household size, farm size, farming experience and wealth (i.e., household assets) [24]. Institutional factors consist of access to extension services and climate information, credit availability and tenure status [38] [39]. Finally, social factors include farmer-to-farmer extension services and the number of relatives living nearby [33] [40]. These determinants may assist or restrict adaptation choices. As [41] rightly remarked, farmers are the first people confronting climate variability and changes in the agriculture system [41]. Therefore, it is essential to understand the perception and determinants of farmers and their adaptation strategies to climatic changes in order to diminish vulnerability and enhance the overall resilience of the system [37] [41] [42] [43]. Based on several previous studies, the hypothesized variables that affect adaptation option decisions by rice farmers in our analysis are presented in Table 1.

\subsection{Study Area}

This study was performed in 7 districts that ranged from the hilly to Terai belts of Nepal and excluded the mountain belt ${ }^{1}$. The rice production environments of Nepal can be classified into Terai (60 - $900 \mathrm{~m}$ above sea), hilly (1100 - $1500 \mathrm{~m}$ above sea) and mountain (greater than $1500 \mathrm{~m}$ above sea), which contain 75

${ }^{1}$ This is because rice cultivation practices on the mountain belt are very rare and typically different that in the study area. Similarly, the rice cultivation period, cultivation techniques and adoption of adaptation differ from the remaining two belts. 
Table 1. The overall characteristics affecting determinants for the adoption of adaptation options among rural rice farmers.

\begin{tabular}{|c|c|c|c|c|}
\hline Explanatory Variables & Mean & SD & Description & Expected Sign ${ }^{2}$ \\
\hline Age & 47.743 & 13.14 & Continuous & $( \pm)$ \\
\hline Marital status & 0.9301 & 0.255 & Dummy takes the value 1 if married and 0 otherwise & $( \pm)$ \\
\hline Gender & 0.7089 & 0.455 & Dummy takes the value 1 if the gender is male and 0 otherwise & $( \pm)$ \\
\hline Household head & 0.7956 & 0.404 & Dummy takes the value 1 if the $\mathrm{HH}$ head is male and 0 otherwise & $(+)$ \\
\hline Main occupation & 0.9483 & 0.222 & $\begin{array}{l}\text { Dummy takes the value } 1 \text { if the main occupation is farming and } 0 \\
\text { otherwise }\end{array}$ & $(+)$ \\
\hline Household size & 6.4489 & 2.918 & Continuous & $( \pm)$ \\
\hline Level of education & 0.0776 & 0.268 & $\begin{array}{l}\text { Dummy takes the value } 1 \text { if education is higher than the secondary } \\
\text { level and } 0 \text { otherwise }\end{array}$ & $(+)$ \\
\hline Native & 0.8396 & 0.367 & Dummy takes the value 1 if farmers are native and 0 otherwise & $(+)$ \\
\hline Total farmland & 0.6755 & 0.783 & Continuous & $(+)$ \\
\hline Total income & $20,171.52$ & $22,235.46$ & Continuous & $(+)$ \\
\hline Irrigation facilities & 0.4515 & 0.498 & $\begin{array}{l}\text { Dummy takes the value } 1 \text { if the farmer has received irrigation facilities } \\
\text { and } 0 \text { otherwise }\end{array}$ & $(-)$ \\
\hline Fertility of land & 0.4373 & 0.496 & Dummy takes the value 1 if land is fertile and 0 otherwise & $(-)$ \\
\hline Credit & 0.1358 & 0.343 & $\begin{array}{l}\text { Dummy takes the value } 1 \text { if the farmer has access to credit and } 0 \text { oth- } \\
\text { erwise }\end{array}$ & $( \pm)$ \\
\hline Off-farm activities & 0.7671 & 0.898 & $\begin{array}{l}\text { Dummy takes the value } 1 \text { if the farmer has off-farm activities and } 0 \\
\text { otherwise }\end{array}$ & $( \pm)$ \\
\hline $\begin{array}{l}\text { Received weather } \\
\text { information }\end{array}$ & 0.7141 & 0.452 & $\begin{array}{l}\text { Dummy takes the value } 1 \text { if the farmer has received weather related } \\
\text { information and } 0 \text { otherwise }\end{array}$ & $(+)$ \\
\hline Farm experience & 29.009 & 13.29 & Continuous & $(+)$ \\
\hline Market information & 0.4424 & 0.497 & $\begin{array}{l}\text { Dummy takes the value } 1 \text { if the farmer has access to market informa- } \\
\text { tion and } 0 \text { otherwise }\end{array}$ & $(+)$ \\
\hline Distance of road & 0.7257 & 0.446 & $\begin{array}{l}\text { Dummy takes the value } 1 \text { if the farmer has access to roads and } 0 \\
\text { otherwise }\end{array}$ & $(+)$ \\
\hline Organization membership & 0.2096 & 0.407 & $\begin{array}{l}\text { Dummy takes the value } 1 \text { if the farmer has an organization } \\
\text { membership and } 0 \text { otherwise }\end{array}$ & $(+)$ \\
\hline Training & 0.0530 & 0.224 & $\begin{array}{l}\text { Dummy takes the value } 1 \text { if the farmer has received training and } 0 \\
\text { otherwise }\end{array}$ & $(+)$ \\
\hline Extension service & 0.3221 & 0.468 & $\begin{array}{l}\text { Dummy takes the value } 1 \text { if the farmer has access to extension services } \\
\text { and } 0 \text { otherwise }\end{array}$ & $( \pm)$ \\
\hline Access to market center & 0.2186 & 0.414 & $\begin{array}{l}\text { Dummy takes the value } 1 \text { if the farmer has access to a market center } \\
\text { and } 0 \text { otherwise }\end{array}$ & $(+)$ \\
\hline Availability of subsidies & 0.0750 & 0.264 & $\begin{array}{l}\text { Dummy takes the value } 1 \text { if the farmer has access to subsidies and } 0 \\
\text { otherwise }\end{array}$ & $(+)$ \\
\hline Climate change knowledge & 0.7529 & 0.432 & $\begin{array}{l}\text { Dummy takes the value } 1 \text { if the farmer has climate change knowledge } \\
\text { and } 0 \text { otherwise }\end{array}$ & $( \pm)$ \\
\hline Hilly region & 0.5666 & 0.496 & $\begin{array}{l}\text { Dummy takes the value } 1 \text { if the farmer belongs to a hilly region and } 0 \\
\text { otherwise }\end{array}$ & $( \pm)$ \\
\hline
\end{tabular}

Source: Researchers' calculation/assumption.

${ }^{2}$ Sign of expected sigh represent the sigh of the variables. 
percent, 23 percent and 2 percent of the total area, respectively. The Terai belt is considered the grain basket of Nepal and has fertile agricultural land [44]. Three study districts come from the Terai Belt, and four come from the hilly belt. The reason behind choosing 7 districts is that there is one district from each state.

Nepal is a landlocked, least developed country, located in the southern part of the world which is situated at the foothills of the Himalayas between $26^{\circ} 22^{\prime} \mathrm{N}$ and $30^{\circ} 27^{\prime} \mathrm{N}$ north latitude and $80^{\circ} 04^{\prime} \mathrm{E}$ and $88^{\circ} 12^{\prime} \mathrm{E}$ with the altitudinal variation extends from a mere $60 \mathrm{~m}$ to $8848 \mathrm{~m}$ above sea level (Devkota \& Phuyal, 2016). Nepal has observed varying temperatures, with a $0.04^{\circ} \mathrm{C}$ increase per year in Terai and a $0.09^{\circ} \mathrm{C}$ increase per year in the Himalayas, where there is a higher rate of increase in winter [13]. The recorded rates of warming in the Himalayas are significantly higher than the global average since temperature in Nepal has increased by $1.8^{\circ} \mathrm{C}$ during last 32 years [8] [45] [46]. The distribution of rainfall has a wide range and is mostly linked with monsoon winds blowing from the Bay of Bengal. Nepal receives $80 \%$ of its rainfall during the monsoon season where the mean annual precipitation were found to be around $1800 \mathrm{~mm}$ [47] [48]. The main season for rice receives monsoon rain. Terai districts normally fall in irrigated rice fields, while hilly districts cover both irrigated and rain-fed rice fields due to topographical variations. [35] remarked that average household characteristics play an important role in shaping the decision-making process for climate change adaptation.

\subsection{Sampling, Questionnaire and Data Collection}

The study area selection was made based on rice pocket areas from different ecological zones in Nepal. As [35] mentioned in their study, such a study area selection was made based on rice cropping regardless of cropping patterns, irrigation networks and climate prone zones. To select the study sites, this study used multi-sampling techniques. In the first stage, the seven districts of Nepal (one each from each state) were randomly selected for the overall study area. Telephone inquiries were made to each district agricultural office in order to collect rice pocket areas, which were mostly rice cultivated areas, within the district. In the second stage, $14 \mathrm{VDC}^{3} \mathrm{~s}$ (two from each district) were selected as the rice pocket area. Further telephone inquiries were made to each VDC secretary and social mobilizer in order to cross-check the given information from each district agricultural office. In the third stage, 28 rice pocket wards (two wards from each VDC), based on the information provided by the VDC secretary and social mobilizer, were selected. In the fourth stage, 28 farmers were selected from each ward on a convenience ${ }^{4}$ basis. During our field visit, we found that the in${ }^{3}$ VDC stands for Village Development Committee

${ }^{4}$ This study encountered difficulties in selecting farmers on the first day, since most farmers are not available in their houses when the enumerator was present in the area, which effected the selection procedure during sampling due to the availability of farmers in their home at the time of data collection. However, precautions were taken in regard to the distance to each household for the questionnaires. After every $\mathrm{HH}$ questionnaire was filled, few surrounding houses were left in regard to coverage of the entire study area. 
formation provided was correct, and the selected VDCs were the best rice pocket $\mathrm{VDCs}^{5}$ in the district. We excluded urban cities and VDCs under the assumption that cities and urban VDCs may be influenced by market-based adaptations. Selecting VDCs, therefore, had the advantage of a lesser influence by this market driven adoption, which was the primary reason to select VDC as the study area. The overall district, VDC, ward selection and number of respondents from each PSU are presented in Table 2.

The survey was conducted between January and February of 2017. For the data collection, a total of 773 farmers were interviewed, irrespective of gender, farm size or tenancy status, through a farm household survey. Interviews were conducted for the 2016 crop year since the main season rice cultivation in Nepal occurs from June/July to October/November of each year. A fully structured questionnaire was used to gather information on socioeconomic and other characteristics of adaptation. Prior to the study, a pre-testing of the questionnaire was performed to avoid missing any important information. The enumerators received field training on the study objectives and the farm household survey. Both descriptive and inferential statistics were performed. STATA version 13 was used for statistical purposes. All necessary correction checks, such as multicollinearity and heteroscedasticity, were performed and corrected as needed, which is depicted in Table 3.

\section{Data Analysis and Presentation}

\subsection{Socio-Economic Characteristics of the Respondents}

A majority of respondents, $87.97 \%$, were within the working age (15 to 64 years), and $33 \%$ of respondents were youths involved in rice cultivation. This indicates a potential for active labor participation in rice production in Nepal. The average age of the respondents was 46.5 years, ranging from the highest age of 86 years to the lowest age of 18 years. Most of the respondents were male $(70.1 \%)$, while the rest were female. Two noticeable facts about the low participation were the language barrier in Terai and the male as the household head. In both situations, females were less likely to respond to the enumerator with the presence of her husband and the laws in their home. Among the respondents, 93\% were married, and $79.6 \%$ were the household head. The average HH size of the respondents was approximately 6 members. It was also observed that $649(83.9 \%)$ respondents were local people living in the area for very long period of time, while $16.1 \%$ migrated for their betterment and farming purposes.

The education level of the farmers may be helpful when searching for information from various sources on agro-farming issues on the verge of a changing climate and adaptation strategies. In total, $67.5 \%$ of the respondents had a formal education, ranging from primary $(41.52 \%)$ to college level education $(10.2 \%)$, whereas only 65 respondents $(8.4 \%)$ received a vocational education. Most of the rural farmers (98\%) in the study area declared agriculture as their ${ }^{5}$ In each selected ward, rice farm households contained more than $90 \%$ of respondents. 
Table 2. Study districts, VDC, wards and respondents.

\begin{tabular}{cccc}
\hline District & VDC & Selected wards ${ }^{6}$ & $\begin{array}{c}\text { Number of farmers } \\
\text { interviewed }\end{array}$ \\
\hline \multirow{2}{*}{ Ilam } & Godak & $3 \& 4$ & 56 \\
& Sangrumba & $2 \& 5$ & 56 \\
Bara & Manaharwa & $7 \& 9$ & 56 \\
& Rampurwa & $5 \& 6$ & 55 \\
Sindhuli & Bhimsthan & $3 \& 4$ & 52 \\
& Kapilakot & $6 \& 9$ & 54 \\
Syangja & Thumpokhari & $5 \& 8$ & 54 \\
& Swarek & $7 \& 8$ & 55 \\
Surkhet & Manpur & $1 \& 6$ & 56 \\
& Goltakuri & $2 \& 3$ & 56 \\
Kailali & Babiyachaur & $2 \& 8$ & 56 \\
& Kunathari & $1 \& 2$ & 55 \\
Total & Narayanpur & $1 \& 2$ & 56 \\
& Manuwa & $3 \& 6$ & 773 \\
\hline
\end{tabular}

Source: Researchers' calculation.

Table 3. Hypothesis testing for model significance and predictive power.

\begin{tabular}{|c|c|c|c|c|c|c|c|}
\hline Adaptation options & $\begin{array}{c}\mathrm{X}^{2} \\
\text { (chi-square) }\end{array}$ & $\begin{array}{l}\text { Degree } \\
\text { of } \\
\text { freedom } \\
\text { (df) }\end{array}$ & $\begin{array}{c}P \\
\text { level }^{\mathrm{b}}\end{array}$ & $\begin{array}{c}-2 \log \\
\text { likelihoods }\end{array}$ & $\mathrm{AIC}^{\mathrm{a}}$ & $\begin{array}{c}\text { Model } \\
\text { correctness }^{c} \\
(\%)\end{array}$ & Pseudo-R ${ }^{2}$ \\
\hline No adaptation & 156.68 & 25 & 0.00 & -327.95 & 707.89 & 79.43 & 0.28 \\
\hline $\begin{array}{l}\text { Using climate smart } \\
\text { verities }\end{array}$ & 176.36 & 25 & 0.00 & -434.15 & 920.29 & 70.00 & 0.19 \\
\hline $\begin{array}{l}\text { Denser plantation } \\
\text { of local seeds }\end{array}$ & 56.05 & 25 & 0.00 & -274.94 & 601.88 & 86.80 & 0.09 \\
\hline $\begin{array}{l}\text { Selecting short } \\
\text { duration rice crops }\end{array}$ & 116.61 & 25 & 0.00 & -395.76 & 843.55 & 76.20 & 0.16 \\
\hline Rice crop switching & 84.91 & 25 & 0.00 & -155.19 & 362.39 & 93.66 & 0.20 \\
\hline $\begin{array}{l}\text { Use of chemical } \\
\text { fertilizers }\end{array}$ & 154.17 & 25 & 0.00 & -413.50 & 879.01 & 74.26 & 0.20 \\
\hline Use of vitamins & 151.25 & 25 & 0.00 & -222.06 & 496.125 & 86.29 & 0.34 \\
\hline Change in land size & 81.64 & 25 & 0.00 & -111.49 & 274.977 & 95.86 & 0.18 \\
\hline Off-farm activities & 87.36 & 25 & 0.00 & -85.07 & 220.133 & 96.45 & 0.24 \\
\hline $\begin{array}{l}\text { Change in nursery } \\
\text { date }\end{array}$ & 58.49 & 25 & 0.00 & -453.93 & 959.856 & 70.12 & 0.06 \\
\hline $\begin{array}{l}\text { Changing planting } \\
\text { dates }\end{array}$ & 68.32 & 25 & 0.00 & -420.53 & 893.060 & 74.51 & 0.09 \\
\hline $\begin{array}{l}\text { Change in } \\
\text { irrigation practice }\end{array}$ & 132.83 & 25 & 0.00 & -214.07 & 480.137 & 89.78 & 0.48 \\
\hline
\end{tabular}

${ }^{a}$ AIC (Akaike information criterion) measures the relative quality of the statistical model. ${ }^{b} P$ level shows the statistical significance needed to reject the null hypothesis (H0). ${ }^{c}$ This is based on the classification table. Source: Modified from [35].

${ }^{6}$ Each selected ward represent to primary sample unit (PSU) to collected $\mathrm{HH}$ information regarding perception, determinations and barriers of climate change adaptation. 
major occupation. The average land holdings of such farmers were 26.70 kattha, among which the average rice growing land was 20.15 kattha. This shows that people only had more available land holdings and rice cultivation when the land was suitable. In addition, there may be several other causes, such as upland, dry land and other types of land, that restrict rice farmers to cultivating less land than they actually possess.

\subsection{Climate Change Perception among Rice Farmers}

Perception is one of the most important factors determining the willingness to accept adaptation options, and it is considered the first step in the process for a farmer's adaptation to climate change [40] [49]. Farmers should first perceive that there is climate change in order to take necessary adaptive strategies [39]. A better understanding about perception helps to develop and design effective plans and policies to support successful adaptations in the agricultural sector, including rice production. The surveyed farmer household respondents were asked about their perception of climate change in regard to various climate variables over the past 30 years. Temperature was separated into maximum temperature, minimum temperature, day time temperature, night time temperature, summer temperature and winter temperature, and precipitation was divided into increased, decreased, consistent and unknown precipitation.

This study found that approximately $81 \%$ of rice farming households have heard of and talked about climate change. Districts such as Bara (95\%) and Syangja (91\%) had a greater percentage of respondents that have heard of and talked about climate change when compared to other districts. A total of $80.7 \%$ of the respondents mentioned that they were aware of changing temperature. Among the rice farmers, $80 \%$ of the farmers mentioned that temperature has increased during the 30-year time span. Approximately $77 \%$ of respondents stated that there has been an increase in maximum temperature, as well as an increase in minimum temperature (89\%), day time temperature (90\%), night time temperature $(84 \%)$, summer temperature (90\%) and winter temperature $(53 \%)$. Similar to temperature, $90 \%$ of farmers stated that precipitation has deceased sharply during the past 30 years. Their major observations showed that rainfall patterns have decreased, along with the change in timing for rain. Farmers stated that before the most recent 30 years, rainfall was regular and predicted, but now it is irregular and unpredictable. Such a sharp decrease in rainfall makes it harder for them to cultivate their farmland.

As a result, production in the study area has already been impacted by such climatic variations. Overall, $91 \%$ of farmers argued that there has been a change in production among them; a total of $77 \%$ mentioned that their production has decreased, $12 \%$ believed that their production has increased, and $2 \%$ felt no change in production at all, while the remaining 9\% were unsure about the change. This shows that a majority of farmers are facing a food problem due to changes in temperature and rainfall patterns. 


\subsection{Farm Level Adaptation Strategies}

Discovering adaptation strategies made by farmers is useful to obtain an understanding of the adaptive capacity of an agricultural system [42] Farmers in the study area were asked to reveal their major adaptation strategies in response to climate change, and the farmers identified that there are 12 major adaptation strategies that are commonly used in practice. Such adaptation options were first selected from the literature and discussed with experts before posing them directly to the farmers. Farmers were also asked to add new adaptation options, if any, during the $\mathrm{HH}$ survey, but no additional adaptation options were found. Figure 1 shows the major and common adaptation strategies adopted by farmers in order to cope with a changing climate.

Among farmers, $73 \%$ argued that they have been adopting several adaptation options for rice farming, while $27 \%$ had not yet started any adaptation mechanism. It was also observed that in the hilly districts, there were still less adaptation practices that have prevailed. Among the study districts, farmers belonging to Terai had adopted more in comparison to farmers living in the hilly region. Farmers from Ilam and Surkhet had a low adaptation to available adaptation options as only $30 \%$ of the farmers from Ilam and $40 \%$ of those from Surkhet had adopted options for their rice farm.

\subsection{Knowledge of Climate Change Adaptation Strategies}

Several studies, including governmental as well as academic studies, have shown that rice farmers in Nepal have initiated several domestic activities and actions to respond to climate change in their fields [24] [25] [28] [29] [50]. However, such adaptations are different based on location, as stated above. Our study revealed that rice farmers have a sufficient knowledge of climate change and its impact on

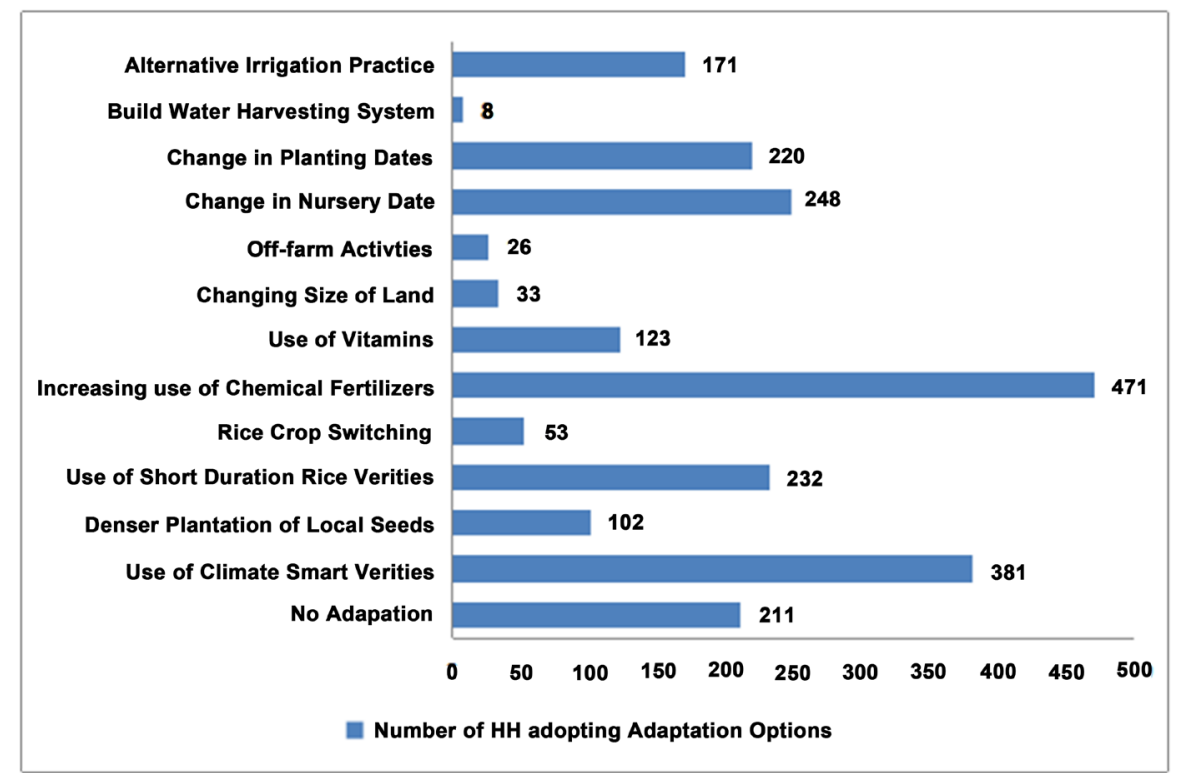

Figure 1. Main adaptation practices of farmers in the study area. 
their farmland. A total of more than $90 \%$ of rice farm households believe that climate change can reduce their soil fertility, negatively affect their rice production and increase the invasion of pests and diseases that hamper rice production. Similarly, $80 \%$ of the abovementioned farmers state that climate change may cause extreme changes in weather conditions, which can cause sickness among farming families. They believe that this can be reduced with supplementary irrigation practices that are meant for coping with climate change. Likewise, more than $60 \%$ of farmers argue that such changes in climate can be mitigated by seeking out early warning information, planting improved verities of rice seeds and participating in workshops and conferences related to rice farming. Only half of the respondents mention the shifting of the planting date and insuring crops against risk as coping mechanisms.

\subsection{Barriers when Adopting Available Adaptation Options}

Barriers of adaptation can be defined as factors, conditions or obstacles that are believed to reduce the effectiveness of the farmers' adaptation strategies [51] [52]. The major farmer adaptation barriers are socio-ecological factors, psychological factors and resource constraints, which arise due to poverty levels, lack of information and communication on adaptive measures, lack of access to credit, and the perception of the importance of climate change and adaptation. Such barriers can be overcome with creative management, changed thinking and concerned effort [33] [52].

It is not easy to adopt available adaptation options, and as expressed by the farmers, this difficulty is due to one of these causes. Rice farmers were asked to state the factors that hinder them from adopting available adaptation options. It was found that Nepalese rice farmers face various hindrances when adopting available adaptation options best for them. Factors such as inadequate capital, poor access to weather forecasts and climate change information, and inadequate awareness programs on climate change from governmental and non-governmental agencies were major barriers for more than $90 \%$ of farmers. Similarly, more than $80 \%$ of farmers stated that the high cost of improved seeds, fertilizers and irrigation, the inadequate knowledge of coping mechanisms and resiliency and the inadequate access to credit facilities were major among the given hindrances to rice farmers. Furthermore, there were several other barriers that rice farmers are facing, such as insufficiency of manpower, inadequate government policies and old farming technology and equipment. Among the barriers, the top five barriers that the rice farmers cope with in a changing climate can be observed in Figure 2.

Farmers argued that capital inadequacy was the first barrier, as they are poor. Most of the other adaptations were also related to price, which is again related to capital. They mentioned that the high cost of fertilizer and the lack of credit access hinder their adaptation capacity, along with insufficient information and inadequate awareness. 


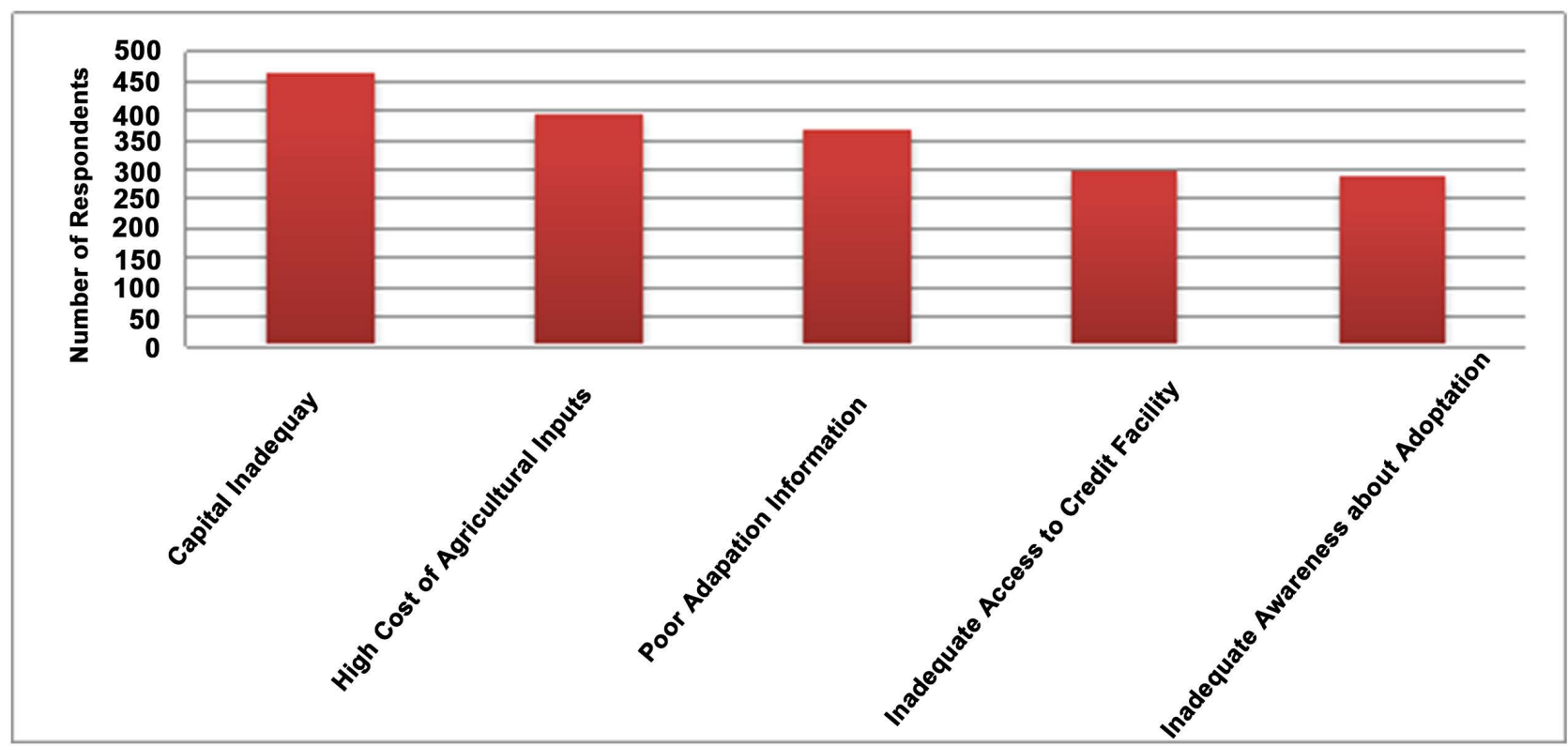

Figure 2. Top five barriers for rice farmers when coping with a changing climate.

\subsection{Determinants for the Adoption of Climate Change Adaptation Options}

Determinants of adaptation options refer to the factors that decisively affect the nature or outcome of the adaptations. The IPCC defined climate change determinants as "the considerable attention that has been devoted to the characteristics of systems that influence their propensity or ability to adapt and/or their priority for adaptation measures". Knowing the determinants of choice for climate change adaptation strategies is very vital in developing intervention measures for those key perceived determinants to improve adaptive capacities of farmers [37]. The statistical and econometric software STATA (version 13) was used to estimate the parameters of the multiple regression that determined the climate change adaptation options.

As such, the binomial logit regression model (with cross-sectional data) was adopted to check the determinant factors for the adoption of adaptation options. Such data analyses involved two problems: the heteroscedasticity of the error term and multicollinearity among explanatory variables [53]. The Collin test was performed to address the problem of multicollinearity and found that the VIF score for all models was less than 2. The Collin test was used against the Breusch-Pagan test for multicollinearity in this analysis since the Collin test allows for the direct estimation of multicollinearity after a logit regression, while the Breusch-Pagan test requires OLS estimation. Similarly, we estimated a robust logit regression in order to the prevent model of heteroscedasticity.

Some post estimation tests, such as the fit test and the classification table test, were also performed to understand the fit of our model. We tested all of our models for the significance and accuracy of the predictions. A classification table 
(shown in Table 3) was used to measure the extent to which our model accuracy predicted dependent variables. [35] argued that a higher percentage from the calculation indicates a better fit of the model.

The post estimation found that the overall percentage correctness for all models was more than $70 \%$, which confirmed a better fit of all models used in our study. Similarly, the $\chi^{2}$ value was significant, and the value of the Pseudo- $\mathrm{R}^{2}$ ranged from 0.06 to 0.48 , which indicated that all model selected for this study fit and can accurately estimate the determinants and the perception of farmers for the adoption of climate change adaptation options.

Since the study aims to measure individual adaptation options, we have 12 different dependent variables (i.e., adaptation options for the farmers) for the same explanatory variables. In terms of $\mathrm{F}$ and $\mathrm{R}^{2}$ values, the overall mean regression of the variable is jointly important in the implicated adoption of available adaptation options for the farmers. For simplicity, this study explains the models per its regression result, which is given in Appendix 1.

\subsection{Model 1: No Adaptation}

In Model 1, eight variables were found to significantly affect the rice growing farmers' choice to not adapt. Such variables were household size, irrigation facilities, availability of credit, access to roads, extension service availability, access to market centers, availability of subsidies and farmers who lived in the hilly region. Among these significant variables, availability of credit, access to roads and farmers who lived in the hilly region were significant at the $1 \%$ level of significance, which indicated the probability of high level association with the no adaptation model. However, road access and credit availability had negative signs, which revealed that if the credit availability for the farmers was sufficient and road access was near the household, the probability of adaptation increased significantly, with other conditions remaining the same. Farmers who lived in hilly regions resulted in a significant and positive sign, meaning that if the farmers lived in a hilly region, the probability of the adoption of given adaptation options was lower compared to those farmers who lived in Terai. Variables such as irrigation facilities, extension services and availability of subsidies were statistically significant at the $5 \%$ level of significance. Here, the availability of subsidies and extension services also had a negative sign, indicating that based on availability, the probability of adaptation by rice farmers increased. On the other hand, irrigation facilities showed a positive sign, meaning the more irrigation availability there was for the farmers, the less likely the adoption of available adaptation options. Other variables, such as household size and market center, showed statistical significance at the $10 \%$ level of significance, which indicated a lower association between the dependent variable. The household size resulted in a negative sign, meaning that the probability of adaptation increased with the increase in household size. In addition, market access showed a positive sign, which signified that the probability of adaptation was lower as the farmer gained easy market access (this variable contradicted our hypothesis). 


\subsection{Model 2: Change in Rice Verities}

In Model 2, eight variables were found to significantly affect the rice-growing farmers' changes in rice verities. Such variables were main occupation, total farmland, fertility, access to roads, membership in an organization, availability of subsidies, knowledge about climate change and living in a hilly region. Among these significant variables, total farmland, availability of subsidies and living in a hilly region were significant at the $1 \%$ level of significance, which indicated the probability of a high-level association with changes in rice varieties. However, all variables had a negative sign, which revealed that if a farmer possessed more farmland, received available subsidies and lived in a hilly region, the probability of changes in rice variability was lower. Variables such as main occupation, distance to roads, membership in an organization and knowledge on climate change were statistically significant at the 5\% level of significance. Among these variables, the distance to roads, membership in an organization and knowledge on climate change were positively associated with the dependent variables, which signified that the probability of changes in rice varieties increased per the increase in given variables. However, main occupation had a negative sign, which indicated that the probability for changing rice variability was negative. Apart from this, fertility was statistically significant at the $10 \%$ level of significance and possessed a negative sign; this indicated that the probability of change in rice varieties negatively depended upon fertility level. If farmers had fertile land, there were fewer adoptions of adaptation options.

\subsection{Model 3: Denser Plantation of Rice}

In Model 3, seven variables were found to significantly affect the denser plantation of rice as an adaptation option for the farmers. Such variables were gender, market information, knowledge of climate change, level of education, received weather information, access to roads and living in a hilly region. Hilly regions showed statistical significance at the $1 \%$ level of significance and possessed a negative sign, which implied that the probability of planting denser rice was less in hilly regions compared to the Terai region. Similarly, gender, market information and climate change knowledge showed statistically significant at the 5\% level of significance and had a positive sign. This implies that the probability for the denser plantation of rice increased for male gender, possession of market information and receipt of climate change knowledge. Additionally, the level of education, received weather information and access to road distance were statistically significant at the $10 \%$ level of significance. Here, received weather information and access to road distance had positive signs, indicating that the probability of increasing the denser plantation of rice increased based on information and road access, but the level of education showed a negative sign, indicating that such an adaptation practice decreased when it had a significantly negative sign. The major reason might be that education provides various other techniques and adaptation options to rice farmers other than denser planting. 


\subsection{Model 4: Use of Short Duration Rice Varieties}

In Model 4, ten variables were found to significantly affect the use of short duration rice varieties as an adaptation option for farmers. Such variables were age, irrigation, off-farm activities, access to roads, membership in an organization, availability of subsidies, total farmland, fertility and farmers who lived in hilly regions. Variables such as age, irrigation, off-farm activities, farm experience, access to roads, membership in an organization, availability of subsidies and farmers who lived in hilly regions were statistically significant at the $1 \%$ level of significance. Some variables, such as irrigation, off-farm activities, farm experience and farmers who lived in hilly regions, were negatively associated with the dependent variables, meaning that the probability of using short duration of varieties was lower with the increase in the use of mentioned variables. However, some variables, such as age, road-distance, membership in an organization and availability of subsidies had a positive sign, indicating that the probability of use for short duration rice varieties increased with the increase in age per year, distance to road access, membership in an organization and availability of subsidies. Similarly, total farmland and fertility were negatively associated with the use short duration of rice varieties at the $5 \%$ and $10 \%$ level of significance, respectively. This signified that as total farmland and fertility increased, the probability of use of short duration rice varieties decreased, and vice versa.

\subsection{Model 5: Rice Crop Switching}

In Model 5, seven variables were found to significantly affect rice crop switching as an adaptation option for farmers. Such variables were credit, market information, member of an organization, irrigation, training, household head and fertility. In this model, explanatory variables such as access to credit, market information and member of organizations were statistically significant at the $1 \%$ level and had a positive sign. This indicated that the probability of rice crop switching increased with an increase in access to credit, market information and organization memberships. Similarly, irrigation and training were statistically significant at the $5 \%$ level of significance and both had negative signs. This indicated that the probability of rice crop switching decreased if there was a sufficient level of irrigation availability and proper training for rice farmers. Likewise, household head and fertility level were statistically significant at the $10 \%$ level of significance. Household head was positively significant with rice crop switching, which meant that if the household head was male, then the probability of crop switching was higher. However, fertility was significant with a negative sign, indicating that the probability of not changing the rice crop was high with more fertile land. Only degraded or unsuitable land for the rice cultivation of land-holding farmers switched their farm practice.

\subsection{Model 6: Increase in the Use of Fertilizer}

In Model 6, six variables were found to significantly affect the increase in the use 
of fertilizer as an adaptation option for farmers. Such variables were irrigation, fertility, total farmland, road access, extension services and people who lived in the hilly region. Access to roads, extension services to farmers and people living in the hilly region were statistically significant at the $1 \%$ level of significance. Two variables (i.e., access to roads and extension services) had positive signs, indicating that the probability of increasing the use of fertilizer increased with road access and agricultural extension services available to farmers. However, the hilly region showed a negative sign, indicating that the probability of using fertilizer by hilly farmers was less compared to farmers from Terai. Similarly, irrigation and fertility were significant statistically at the $5 \%$ level of significance and had negative signs, which indicated that with the availability of irrigation and fertility of soil, the probability of the increasing use of fertilizer decreased. Studies argued that proper irrigation and proper fertile land required less fertilizer compared to others. Likewise, total farmland was statistically significant at the $10 \%$ level of significance and had a negative sign, which indicated that farmers with more farmland had a lower probability of using more fertilizer.

\subsection{Model 7: Use of Vitamins}

In Model 7, six variables were found to significantly affect the use of vitamins as an adaptation option for farmers. Such variables were the availability of credit, access to the market center, access to roads, extension services, whether the people were native and whether the people lived in a hilly region. Among the significant variables, availability of credit, access to the market center and living in hilly regions were statistically significant at the $1 \%$ level of significance. Here, credit and access to the market center had positive signs, which indicated that the probability of using vitamins increased with the availability of credit to farmers, as well as market access. However, farmers living in a hilly region had a negative sign, which showed that the probability of using vitamins by farmers was less compared to famers living in Terai. Variables such as road access and extension services had statistical significance at the 5\% level of significance. Here, distance to roads showed a positive relationship between the use of vitamins, while extension services were negatively significant. This signifies that the probability of using vitamins increased with access to roads, whereas extension services helping farmers by providing timely information and methods for coping reduced the use of vitamins. However, native people had statistical significance at the $10 \%$ level of significance and a negative sign, meaning that the probability of using vitamins increased among migrated farmers. This may be the reason why there was less experience on new farmland.

\subsection{Model 8: Changing Land Size}

In Model 8, five variables were found to significantly affect changing land size as an adaptation option for farmers. Such variables were received weather information, market information, availability of subsidies, access to the market center 
and people who lived in hilly region. Availability of subsidies had statistical significance at the $1 \%$ level of significance and a positive sign, which indicated that the probability of changing land size increased with the availability of subsidies. Variables such as received weather information and market information were statistically significant at the $1 \%$ level of significance and had a positive sign. This implied that the probability of changing land size increased with weather information received and proper market information. Similarly, the market center and people who lived in hilly regions were statistically significant at the $10 \%$ level of significance and had a positive sign. This indicated that the probability of changing land size increased with the increase in access to the market center and people who lived in the hilly region.

\subsection{Model 9: Off-Farm Activities}

In Model 9, five variables were found to significantly affect off-farm activities as an adaptation option for farmers. Such variables were main occupation, household size, farm experience, off-farm activities and people who lived in a hilly region. Variables such as farm experience, people who lived in a hilly region and off-farm activities were statistically significant at the $1 \%$ level of significance. Off-farm activities and farm experience had a positive sign, which indicated that the probability of having off-farm activities decreased with the farmers' involvement in off-farm activities and farm experience. However, people who lived in a hilly region showed a positive sign with off-farm activities, which signified that the probability of having off-farm activities was high for a farm household containing people who lived in a hilly region. Similarly, variables such as main occupation and household size were significant at the 5\% level of significance. Main occupation had a negative sign, which indicated that the farmers were less likely to work on off-farm activities. On the other hand, household size had a positive sign, which indicated that the probability of having off-farm activities increased with the size of the household. If the household had a large family, they were likely to have members involved with off-farm activities compared to households with less family members.

\subsection{Model 10: Change in Nursery Data}

In Model 10, four variables were found to significantly affect the change in nursery date as an adaptation option for farmers. Such variables were gender, market center, irrigation facilities and availability of subsidies. Two variables (i.e., irrigation facilities and availability of subsidies) were statistically significant at the $1 \%$ level of significance. Here, irrigation facilities had negative significance, which indicated that the probability of change in nursery date reduced with the availability of irrigation facilities. However, the availability of subsidies had a positive sign, indicating that the probability of change in nursery date increased with the availability of subsidies. Likewise, variables such as gender and access market centers were statistically significant at the $5 \%$ level of significance and 
had a positive sign. This indicated that the probability of change in nursery date increased as male gender and access to market center increased.

\subsection{Model 11: Change in Planting Date}

In Model 11, seven variables were found to significantly affect the change in planting date as an adaptation option for farmers. Such variables were household size, fertility, access to market center, irrigation facilities, access of subsidies, credit availability and extension services. Variables such as irrigation facilities, access to market center and subsidies were statistically significant at the $1 \%$ level of significance. Irrigation facilities had a negative sign, which indicated that the probability of change in planting date decreased with the availability of irrigation facilities. However, access to the market center and the availability of subsidies had a positive sign, which indicated that the probability of a change in planting date increased with access to the market center and the availability of subsidies. Similarly, credit availability was statistically significant at the $5 \%$ level of significance. It had a negative sign, which indicated that the probability of a change in planting date decreased with credit availability. In regard to credit, farmers were less fearful of cultivating their farms from climatic anomalies. This helps them farm on time. Household size, extension services and fertility were statistically significant at the $10 \%$ level of significance. Household size showed a negative sign, which indicated that the probability of a change in planting date decreased with the increase in household size, and vice versa. Unlike household size, fertility and extension services had a positive sign, which signified that probability of a change in planting date increased with the fertility of land and the availability of extension services.

\subsection{Model 12: Use of Alternative Irrigation}

In Model 12, nine variables were found to significantly affect alternative irrigation as an adaptation option for farmers. Such variables were main occupation, irrigation facilities, training, access to the market center, credit availability, market information, access to roads, and whether the people were native and lived in a hilly region. Explanatory variables, such as irrigation facility, credit availability and people who lived in a hilly region were statistically significant at $1 \%$ level of significance, but irrigation and hilly regions had negative sign, while credit facilities had a positive sign. This indicated that the probability of using alternative irrigation was lower for farmers who already had irrigation facilities and lived in hilly regions. However, credit showed a positive sign, indicating that the probability of using alternate irrigation increased with the increase in credit facilities for farmers. Similarly, market information, native people, access to roads, training and access to the market center were statistically significant at the $5 \%$ level of significance. Market information showed a positive sign, which indicated that the probability of using alternative irrigation increased with proper market information given to the farmers. Apart from this, native people, road 
distance, training and access to the market center had negative signs, indicating that the probability of using alternative irrigation decreased among native farmers compared to migrated farmers, as well as farmers who received proper training and had access to roads and market information. Likewise, the main occupation was statistically significant at the $10 \%$ level of significance and showed a positive sign, which indicated that the probability of using alternative irrigation remained high for farmers whose main occupation was solely farming compared to people who had several occupations.

\section{Conclusion}

This paper examines the perception, determinants and barriers for the adoption of climate change adaptation options among Nepalese rice farmers. This study uses a binomial logit model to access determinants of the farmers' adaption choices in the face of climate change. The dependent variables are 11 adaptation options, as well as a no-adaptation option, while the explanatory variables are socio-economic and other relevant factors. It is found that the majority of respondents for all districts have heard about climate change. Approximately $80.7 \%$ of respondents from rural farmlands stated that temperature has increased during the 30 -year time period, whereas more than $90 \%$ of farmers believed that rainfall has decreased for the same period. Such fluctuations in climatic anomalies have hampered rice production, and greater than $90 \%$ of the farmers argued about this. To protect their land from such changes, $73 \%$ of farming households have taken adaptive measures, which they believe to help in limiting the adverse impact of climate change on their rice farming. Such adaptations are high in the Terai region and low in the hilly region. The major adaptation options that farmers use in rice farming are changes in rice varieties, denser plantation of rice, use of short duration rice varieties, rice crop switching, increase in the use of fertilizer, use of vitamins, changing land size, off-farm activities, changes in nursery date, changes in planting date and the use of alternative irrigation. Rice farmers in the study area had a sufficient knowledge on climate change and its impact, and more than $90 \%$ believed that climate change can reduce their soil fertility, negatively affect their rice production and increase the invasion of pests and diseases that hamper with rice production. Furthermore, $80 \%$ of farmers argue that climate change may cause extreme changes in weather conditions, which can cause sickness among farming families. Farmers believe that such impacts can be reduced with supplementary irrigation practices. Overall, more than $60 \%$ of farmers also state that seeking early warning information, planting improved verities of rice seeds and participation in workshops and conferences related to rice farming could be other coping mechanisms. Farmers have been facing many barriers to the adoption of such adaptation options that are available to them. Farmers have been hindered by several barriers; among them, the top five hindrances are the inadequacy of capital, high cost of agricultural inputs, poor adaptation information, inadequate access to credit facilities and inadequate 
awareness of the adaptation options they could adopt on their farmlands. The results from the binomial logit model specify that most of the variables are statistically significant. Various adaptation strategies are significant, but the significance of the variables differ with different models, which indicates that all adaptation options are not influenced by the same variables. The no adaptation model finds that household size, irrigation facilities, availability of credit, access to roads, extension service availability, access to the market center, and the availability of subsidies are significant factor, and farmers who live in a hilly region had a statistically significant relationship with these variables. As different adaptation strategies are followed by the farmers, there are several different variables influencing these adaptations, as discussed earlier. This indicates that adaptation strategies for farmers differ with adaptation options, as well as the knowledge that they perceive regarding such adaptation options. Therefore, government policy should target the improvement of these significant determinants to boost farmer adaptations and thus reduce vulnerability. For example, investment in education, the supply of enough agricultural inputs, providing awareness about the use of chemical fertilizers and other adaptation options can be used as appropriate policy options in order to minimize the effect of climate change on rural farmland in Nepal.

\section{Acknowledgements}

The authors would like to acknowledge Author Aid for providing a free journal editing coupon and American Journal Experts for standard editing of the manuscript. The authors also declare that there is no competing interests exist.

\section{References}

[1] IPCC (2007) Impacts, Adaptation and Vulnerability. Contribution of Working Group II to the Fourth Assessment Report of the Intergovernmental Panel on Climate Change. Cambridge University Press, Cambridge.

[2] Dejene, A., Midgley, S., Marake, M.V. and Ramasamy, S. (2011) Strengthening Capacity for Climate Change Adaptation in Agriculture: Experiences and Lessons from Lesotho. Environment and Natural Resource Management Series, No. 18, The Food and Agriculture Organization of United Nations, Rome. http://www.fao.org/docrep/014/i2228e/i2228e00.pdf

[3] Economics of Climate Adaptation Working Group (2009) Shaping Climate-Resilient Development: A Framework for Decision-Making. http://ccsl.iccip.net/climate_resilient.pdf

[4] Jones, L. and Boyd, E. (2011) Exploring Social Barriers to Adaptation: Insights from Western Nepal. Global Environmental Change, 21, 1262-1274. https://doi.org/10.1016/j.gloenvcha.2011.06.002

[5] Prasai, B. (2010) National Issue Paper on the Agriculture Sector (Adaptation). United Nations Development Program, New York.

[6] Maclean, J., Hardy, B. and Hettel, G. (2013) Rice Almanac: Source Book for One of the Most Important Economic Activities on Earth. 4th Edition, International Rice Research Institute, Laguna. 
[7] MoAC (2017) Statistical Information on Nepalese Agriculture: 2009/10. Agri-Business Promotion and Statistics Division, Ministry of Agriculture and Cooperatives, Kathmandu.

[8] Malla, G. (2008) Climate Change and Its Impact on Nepalese Agriculture. The Journal of Agriculture and Environment, 9, 62-71.

[9] Gauchan, D. and Pandey, S. (2011) Socio-Economic Analyses of Farmer Livelihoods, Modern Variety Adoption and Economics of Rice Production in Stress-Prone Rain-Fed Areas of Nepal. International Rice Research Institute, Laguna.

[10] MOAD (2015) Rice Varietal Mapping in Nepal: Implication for Development and Adaptation. Crop Development Directorate, Ministry of Agriculture and Development, Lalitpur.

[11] Tripathi, B.P., Mahato, R.K., Yadav, R.B., Sah, S.N. and Adhikari, B.B. (2012) Adapting Rice Technologies to Climate Change. Hydro Nepal Journal of Water Energy and Environment, 11, 69-72.

[12] MoAC (2013) Statistical Information on Nepalese Agriculture: 2009/10. Agri-Business Promotion and Statistics Division, Ministry of Agriculture and Cooperatives, Kathmandu.

[13] Devkota, N. and Phuyal, R.K. (2016) Climatic Impact on Wheat Production in Terai of Nepal. Journal of Development and Administrative Studies, 23, 1-22. https://doi.org/10.3126/jodas.v23i1-2.15445

[14] IRRI (2000) International Rice Research Institute: World Rice Statistics 1993-1994. New Scientist, 176, 23-30.

[15] Karn, P. (2014) The Impact of Climate Change on Rice Production in Nepal. SANDEE Working Paper No. 85, South Asian Network for Development and Environmental Economics (SANDEE), Kathmandu.

[16] Basnet, B.M.S. (2008) Environment Friendly Technologies for Increasing Rice Productivity. Journal of Agriculture and Environment, 9, 34-40.

[17] MoAC (2010) Statistical Information on Nepalese Agriculture: 2009/10. Agri-Business Promotion and Statistics Division, Ministry of Agriculture and Cooperatives, Kathmandu.

[18] Chhetri, N., Chaudhary, P., Tiwari, P.R. and Yadav, R.B. (2012) Institutional and Technological Innovation: Understanding Agricultural Adaptation to Climate Change in Nepal. Applied Geography, 33, 142-150.

https://doi.org/10.1016/j.apgeog.2011.10.006

[19] Bosello, F., Carraro, C. and De Cian, E. (2009) An Analysis of Adaptation as a Response to Climate Change. Working Paper No. 2609, Department of Economics, Ca'Foscari University of Venice, Venezia. https://ssrn.com/abstract=1513286

[20] Mendelsohn, R. (2012) The Economics of Adaptation to Climate Change in Developing Countries. Climate Change Economics, 3, Article ID: 1250006. https://doi.org/10.1142/S2010007812500066

[21] Mendelsohn, R. (2006) The Role of Markets and Governments in Helping Society Adapt to a Changing Climate. Climatic Change, 78, 203-215. https://doi.org/10.1007/s10584-006-9088-4

[22] Pant, K.P. (2011) Economics of Climate Change for Smallholder Farmers in Nepal: A Review. The Journal of Agriculture and Environment, 12, 113-126.

[23] Acharya, S.P. and Bhatta, G.R. (2013) Impact of Climate Change on Agricultural Growth in Nepal. NRB Economic Review, 25, 1-16. 
[24] Tiwari, K.R., Rayahajhi, S., Pokharel, R.K. and Balla, M.K. (2014) Determinants of the Climate Change Adaptation in Rural Farming in Nepal Himalaya. International Journal of Multidisciplinary and Current Research, 2, 234-240.

[25] Thapa-Parajuli, R. and Devkota, N. (2015) Impact of Climate Change on Wheat Production in Nepal. Asian Journal of Agricultural Extension, Economics \& Sociology, 9, 1-14.

[26] Sapkota, S., Paudel, M.N., Thakur, N.S., Nepali, M.B. and Neupane, R. (2010) Effect of Climate Change on Rice Production: A Case of Six VDCs in Jumla District. Nepal Journal of Science and Technology, 11, 57-62.

[27] Dahal, N. (2008) Understanding Climate Change Adaptation Issues in Nepal. The Initiation, 2, 138-144.

[28] Bartlett, R., Bharati, L., Pant, D., Hosterman, H. and McCornick, P.G. (2010) Climate Change Impacts and Adaptation in Nepal. IMWI Working Paper No. 139, International Water Management Institute, Colombo.

[29] Regmi, B.R. and Bhandari, D. (2013) Climate Change Adaptation in Nepal: Exploring Ways to Overcome the Barriers. Journal of Forest and Livelihood, 11, 43-61. https://doi.org/10.3126/jfl.v11i1.8612

[30] Dhakal, S., Sedhain, G.K. and Dhakal, S.C. (2016) Climate Change Impact and Adaptation Practices in Agriculture: A Case Study of Rautahat District, Nepal. Climate, 4, 63.

[31] Khanal, U., Wilson, C., Hoang, V.N. and Lee, B. (2018) Farmers' Adaptation to Climate Change, Its Determinants and Impacts on Rice Yield in Nepal. Ecological Economics, 144, 139-147. https://doi.org/10.1016/j.ecolecon.2017.08.006

[32] Mengistu, D. and Haji, M. (2015) Factors Affecting the Choices of Coping Strategies for Climate Extremes: The Case of Yabello District, Borana Zone, Oromia National Regional State, Ethiopia. Science Research, 3, 129-136.

https://doi.org/10.11648/j.sr.20150304.11

[33] Deressa, T., Hassan, R.M., Alemu, T., Yesuf, M. and Ringler, C. (2008) Analyzing the Determinants of Farmers' Choice of Adaptation Methods and Perceptions of Climate Change in the Nile Basin of Ethiopia. IFPRI Discussion Paper 00798, Environment and Production Technology Division, International Food Policy Research Institute (IFPRI), Washington DC.

[34] Gbetibouo, G.A. (2009) Understanding Farmers' Perceptions and Adaptations to Climate Change and Variability: The Case of the Limpopo Basin, South Africa. IFPRI Discussion Paper No. 00849, Environment and Production Technology Division, International Food Policy Research Institute (IFPRI), Washington DC.

[35] Abid, M., Scheffran, J., Schneider, U.A. and Ashfaq, M. (2015) Farmers' Perceptions of Adaptation Strategies to Climate Change and Their Determinants: The Case of Punjab Province, Pakistan. Earth System Dynamics, 6, 225-243. https://doi.org/10.5194/esd-6-225-2015

[36] Devkota, N. and Phuyal, R.K. (2017) An Analysis of Nepalese Youth Understanding Level on Climate Change. Asian Journal of Economic Modelling, 5, 342-353. https://doi.org/10.18488/journal.8.2017.53.342.353

[37] Mabe, F.N., Sienso, G. and Donkoh, S. (2014) Determinants of Choice of Climate Change Adaptation Strategies in Northern Ghana. Research and Applied Economics, 6, 75-94. https://doi.org/10.5296/rae.v6i4.6121

[38] Hassan, R. and Nhemachena, C. (2008) Determinants of African Farmers' Strategies for Adapting to Climate Change: Multinomial Choice Analysis. African Journal of 
Agricultural and Resource Economics, 2, 83-104.

[39] Bryan, E., Deressa, T.T., Gbetibouo, G.A. and Ringler, C. (2009) Adaptation to Climate Change in Ethiopia and South Africa: Options and Constraints. Environmental Science \& Policy, 12, 413-426. https://doi.org/10.1016/j.envsci.2008.11.002

[40] Deressa, T.T., Hassan, R.M. and Ringler, C. (2011) Perception of Adaptation to Climate Change by Farmers in the Nile Basin of Ethiopia. The Journal of Agricultural Science, 149, 23-31. https://doi.org/10.1017/S0021859610000687

[41] Kabir, M.D.H. (2015) Impact of Climate Change on Agriculture Especially in Jessore and Sathkhira Districts According to Farmers' Mitigation Strategies to Climate Change; Evidence from Farmer Level Data. Journal of Geography and Natural Disasters, 5, Article ID: 1000152.

[42] Reid, S., Smit, B., Caldwell, W. and Belliveau, S. (2007) Vulnerability and Adaptation to Climate Risks in Ontario Agriculture. Mitigation and Adaptation Strategies for Global Change, 12, 609-637. https://doi.org/10.1007/s11027-006-9051-8

[43] Li, C., Ting, Z. and Rasaily, R.G. (2010) Farmer's Adaptation to Climate Risk in the Context of China: A Research on Jianghan Plain of Yangtze River Basin. Agriculture and Agricultural Science Procedia, 1, 116-125.

https://doi.org/10.1016/j.aaspro.2010.09.014

[44] Springate-Baginski, O. and Blaikie, P. (2013) Understanding the Diversity of Participatory Forest Management Livelihood and Poverty Impacts. In: Springate-Baginski, O. and Blaikie, P., Eds., Forests People and Power. The Political Ecology of Reform in South Asia, Taylor \& Francis Group, Abingdon-on-Thames, 116-137.

[45] Shrestha, A.B., Wake, C.P., Mayewski, P.A. and Dibb, J.E. (1999) Maximum Temperature Trends in the Himalaya and Its Vicinity: An Analysis Based on Temperature Records from Nepal for the Period 1971-94. Journal of Climate, 12, 2775-2786. https://doi.org/10.1175/1520-0442(1999)012<2775:MTTITH >2.0.CO;2

[46] Aryal, P. (2015) Climate Change and Food Security: Nepal Perspective. History, 1, 105-109.

[47] Shrestha, M.L. (2000) Interannual Variation of Summer Monsoon Rainfall over Nepal and Its Relation to Southern Oscillation Index. Meteorology and Atmospheric Physics, 75, 21-28. https://doi.org/10.1007/s007030070012

[48] Pokharel, A.K. and Hallett, J. (2015) Distribution of Rainfall Intensity during the Summer Monsoon Season over Kathmandu, Nepal. Weather, 70, 257-261. https://doi.org/10.1002/wea.2544

[49] Maddison, D. (2007) The Perception of Adaptation to Climate Change in Africa. Policy Research Working Paper 4308, The World Bank, Washington DC. https://doi.org/10.1596/1813-9450-4308

[50] Muccione, V., Salzmann, N. and Huggel, C. (2016) Scientific Knowledge and Knowledge Needs in Climate Adaptation Policy: A Case Study of Diverse Mountain Regions. Mountain Research and Development, 36, 364-375. https://doi.org/10.1659/MRD-JOURNAL-D-15-00016.1

[51] Antwi-Agyei, P., Dougill, A.J. and Stringer, L.C. (2013) Barriers to Climate Change Adaptation in Sub-Saharan Africa: Evidence from Northeast Ghana and Systematic Literature Review. CCCEP Working Paper No. 154 \& SRI Paper No. 52, Centre for Climate Change Economics and Policy and Sustainability Research Institute, London.

[52] Van, S.T., Byod, W. and Van, M.T. (2015) Perception of Climate Change Farmer's 
Adaptation: A Case Study of Poor and Non-Poor Farmers in Northern Central Coast of Vietnam. Journal of Basic and Applied Sciences, 11, 323-342.

https://doi.org/10.6000/1927-5129.2015.11.48

[53] Greene, W.H. (2003) Econometric Analysis. Pearson Education, Kannur. 


\section{Appendix I}

\begin{tabular}{|c|c|c|c|c|c|c|c|c|c|c|c|c|}
\hline \multirow[b]{2}{*}{ VARIABLES } & Model 1 & Model 2 & Model 3 & Model 4 & Model 5 & Model 6 & Model 7 & Model 8 & Model 9 & Model 10 & Model 11 & Model 12 \\
\hline & $\begin{array}{c}\text { no_ } \\
\text { adaptation }\end{array}$ & $\begin{array}{c}\text { change_ri } \\
\text { ce_- } \\
\text { varieties }\end{array}$ & $\begin{array}{l}\text { dens- } \\
\text { er_use_- } \\
\text { local_ } \\
\text { seeds }\end{array}$ & $\begin{array}{l}\text { use_short_ } \\
\text { dura- } \\
\text { tion_variei } \\
\text { tes }\end{array}$ & $\begin{array}{l}\text { rice_crop_ } \\
\text { switching }\end{array}$ & $\begin{array}{c}\text { in- } \\
\text { crease_use } \\
\text { _fertilizer }\end{array}$ & $\begin{array}{l}\text { use_of_- } \\
\text { vitamins }\end{array}$ & $\begin{array}{l}\text { chain- } \\
\text { ging_- } \\
\text { landsize }\end{array}$ & $\begin{array}{l}\text { off_farm_ } \\
\text { activities }\end{array}$ & $\begin{array}{l}\text { change_ } \\
\text { nursary_- } \\
\text { date }\end{array}$ & $\begin{array}{c}\text { chang- } \\
\text { ing_plant_ } \\
\text { date }\end{array}$ & $\begin{array}{c}\text { use_altern } \\
\text { ative_ } \\
\text { irrigation }\end{array}$ \\
\hline \multirow{2}{*}{ Age } & 0.00403 & 0.0170 & -0.0288 & $0.0391^{* * *}$ & 0.000399 & -0.0143 & -0.00297 & -0.0367 & -0.00906 & 0.0112 & 0.00557 & -0.0268 \\
\hline & $(0.0150)$ & $(0.0125)$ & $(0.0176)$ & $(0.0126)$ & $(0.0235)$ & $(0.0125)$ & $(0.0180)$ & $(0.0292)$ & $(0.0295)$ & $(0.0119)$ & $(0.0126)$ & $(0.0193)$ \\
\hline \multirow{2}{*}{ Marital_status } & -0.0348 & 0.206 & 0.225 & -0.133 & -0.253 & -0.0582 & 0.841 & 0.540 & -0.472 & 0.00639 & 0.0381 & -0.388 \\
\hline & $(0.386)$ & $(0.346)$ & $(0.512)$ & $(0.359)$ & $(0.623)$ & $(0.347)$ & $(0.587)$ & $(1.091)$ & $(0.921)$ & $(0.335)$ & $(0.351)$ & $(0.547)$ \\
\hline \multirow{2}{*}{ Gender } & -0.183 & 0.139 & $0.836^{* *}$ & 0.401 & 0.101 & 0.0725 & 0.573 & 0.528 & 0.588 & $0.460^{* *}$ & 0.182 & -0.0425 \\
\hline & $(0.264)$ & $(0.234)$ & $(0.329)$ & $(0.252)$ & $(0.416)$ & $(0.235)$ & $(0.397)$ & $(0.593)$ & $(0.604)$ & $(0.233)$ & $(0.241)$ & $(0.380)$ \\
\hline HH_head & $(0.292)$ & $(0.258)$ & $(0.339)$ & $(0.272)$ & $(0.482)$ & $(0.259)$ & $(0.431)$ & $(0.711)$ & $(0.625)$ & $(0.255)$ & $(0.265)$ & $(0.422)$ \\
\hline \multirow{2}{*}{$\begin{array}{c}\text { Main__ } \\
\text { occupation }\end{array}$} & 0.311 & $-0.968^{* *}$ & 0.0882 & -0.260 & 1.121 & -0.354 & 0.329 & -0.0269 & $-1.694^{* *}$ & -0.417 & -0.232 & $1.406^{*}$ \\
\hline & $(0.458)$ & $(0.395)$ & $(0.535)$ & $(0.402)$ & $(1.090)$ & $(0.395)$ & $(0.654)$ & $(0.962)$ & $(0.834)$ & $(0.363)$ & $(0.386)$ & $(0.747)$ \\
\hline \multirow{2}{*}{ Household_size } & $-0.0788^{*}$ & 0.0271 & 0.0421 & 0.0325 & 0.0543 & 0.0370 & 0.0137 & 0.0841 & $0.198^{* *}$ & -0.0333 & $-0.0713^{*}$ & 0.0462 \\
\hline & $(0.0455)$ & $(0.0359)$ & $(0.0452)$ & $(0.0373)$ & $(0.0603)$ & $(0.0373)$ & $(0.0495)$ & $(0.0736)$ & $(0.0988)$ & $(0.0353)$ & $(0.0376)$ & $(0.0502)$ \\
\hline \multirow{2}{*}{$\begin{array}{l}\text { Level_of_- } \\
\text { education }\end{array}$} & 0.271 & -0.191 & $-0.890^{*}$ & 0.490 & 0.463 & 0.0366 & 0.339 & 0.478 & -0.549 & 0.165 & 0.272 & 0.0680 \\
\hline & $(0.368)$ & $(0.322)$ & $(0.508)$ & $(0.330)$ & $(0.505)$ & $(0.329)$ & $(0.475)$ & $(0.648)$ & $(0.878)$ & $(0.314)$ & $(0.328)$ & $(0.510)$ \\
\hline Native & -0.0631 & 0.0921 & -0.0851 & 0.211 & -0.0657 & -0.190 & $-0.655^{*}$ & -0.0203 & -0.0247 & 0.223 & 0.159 & $-0.898^{* *}$ \\
\hline \multirow{2}{*}{$\begin{array}{l}\text { Total_ } \\
\text { farmland }\end{array}$} & 0.257 & $-0.482^{* * *}$ & 0.149 & $-0.348^{* *}$ & 0.107 & $-0.233^{*}$ & -0.137 & 0.165 & -0.00111 & -0.191 & -0.0638 & -0.0272 \\
\hline & $(0.166)$ & $(0.145)$ & $(0.150)$ & $(0.157)$ & $(0.177)$ & $(0.132)$ & $(0.151)$ & $(0.219)$ & $(0.436)$ & $(0.153)$ & $(0.153)$ & $(0.157)$ \\
\hline \multirow{2}{*}{ Total_income } & $4.43 e-07$ & $-7.11 \mathrm{e}-06$ & $-3.85 e-06$ & $3.27 \mathrm{e}-06$ & $5.17 \mathrm{e}-06$ & $-2.42 \mathrm{e}-06$ & $-1.26 \mathrm{e}-06$ & $-5.69 \mathrm{e}-08$ & $-3.24 \mathrm{e}-06$ & $-4.48 \mathrm{e}-07$ & $2.51 \mathrm{e}-06$ & $6.85 \mathrm{e}-06$ \\
\hline & $(6.68 \mathrm{e}-06)$ & $(4.56 \mathrm{e}-06)$ & $(6.26 \mathrm{e}-06)$ & $(4.43 \mathrm{e}-06)$ & $(6.52 \mathrm{e}-06)$ & $(4.86 \mathrm{e}-06)$ & $(5.49 \mathrm{e}-06)$ & $(1.02 \mathrm{e}-05)$ & $(1.53 \mathrm{e}-05)$ & $(4.50 \mathrm{e}-06)$ & $(4.62 \mathrm{e}-06)$ & $(5.52 \mathrm{e}-06)$ \\
\hline \multirow{2}{*}{$\begin{array}{l}\text { Irrigation_ } \\
\text { facilities }\end{array}$} & $0.499^{* *}$ & -0.180 & -0.145 & $-0.888^{* * *}$ & $-0.867^{\star *}$ & $-0.461^{\star *}$ & 0.225 & -0.720 & 0.298 & $-0.721^{\star * *}$ & $-1.101^{\star * *}$ & $-2.632^{* * *}$ \\
\hline & $(0.207)$ & $(0.182)$ & $(0.242)$ & $(0.203)$ & $(0.356)$ & $(0.187)$ & $(0.284)$ & $(0.446)$ & $(0.472)$ & $(0.182)$ & $(0.196)$ & $(0.357)$ \\
\hline \multirow{2}{*}{ Fertile } & 0.283 & $-0.284^{*}$ & -0.0581 & $-0.312^{*}$ & $-0.648^{*}$ & $-0.352^{\star *}$ & -0.314 & -0.0109 & 0.730 & 0.171 & $0.313^{*}$ & -0.327 \\
\hline & $(0.200)$ & $(0.171)$ & $(0.230)$ & $(0.183)$ & $(0.342)$ & $(0.176)$ & $(0.258)$ & $(0.416)$ & $(0.480)$ & $(0.167)$ & $(0.175)$ & $(0.260)$ \\
\hline \multirow{2}{*}{ Credit } & $-1.379^{* * *}$ & 0.369 & 0.443 & 0.0843 & $1.807^{* * *}$ & 0.375 & $1.435^{\star * *}$ & -0.369 & -0.604 & -0.452 & $-0.691^{* *}$ & $1.156^{* * *}$ \\
\hline & $(0.483)$ & $(0.284)$ & $(0.367)$ & $(0.281)$ & $(0.420)$ & $(0.312)$ & $(0.345)$ & $(0.753)$ & $(0.897)$ & $(0.282)$ & $(0.313)$ & $(0.405)$ \\
\hline \multirow{2}{*}{$\begin{array}{l}\text { Offfarm_- } \\
\text { activities }\end{array}$} & 0.173 & -0.0687 & 0.00840 & $-0.353^{* * *}$ & -0.196 & -0.0496 & -0.170 & -0.210 & $-1.211^{* * *}$ & -0.0266 & -0.0138 & 0.0177 \\
\hline & $(0.140)$ & $(0.110)$ & $(0.146)$ & $(0.124)$ & $(0.195)$ & $(0.115)$ & $(0.164)$ & $(0.266)$ & $(0.426)$ & $(0.112)$ & $(0.118)$ & $(0.166)$ \\
\hline \multirow{2}{*}{$\begin{array}{l}\text { Received_ } \\
\text { weather_info }\end{array}$} & -0.165 & 0.257 & $0.560^{*}$ & -0.0870 & 0.698 & -0.0815 & 0.318 & $1.556^{* *}$ & 0.262 & -0.253 & -0.319 & 0.0482 \\
\hline & $(0.249)$ & $(0.211)$ & $(0.319)$ & $(0.224)$ & $(0.439)$ & $(0.219)$ & $(0.311)$ & $(0.786)$ & $(0.596)$ & $(0.205)$ & $(0.215)$ & $(0.315)$ \\
\hline \multirow{2}{*}{$\begin{array}{c}\text { Farm_- } \\
\text { experiance }\end{array}$} & -0.00681 & -0.00231 & 0.0188 & $-0.0375^{* * *}$ & -0.0269 & 0.0189 & 0.0112 & 0.00639 & $-0.0869^{* * *}$ & -0.00581 & -0.00692 & 0.0206 \\
\hline & $(0.0147)$ & $(0.0118)$ & $(0.0164)$ & $(0.0120)$ & $(0.0224)$ & $(0.0121)$ & $(0.0167)$ & $(0.0271)$ & $(0.0303)$ & $(0.0114)$ & $(0.0122)$ & $(0.0185)$ \\
\hline
\end{tabular}




\section{Continued}

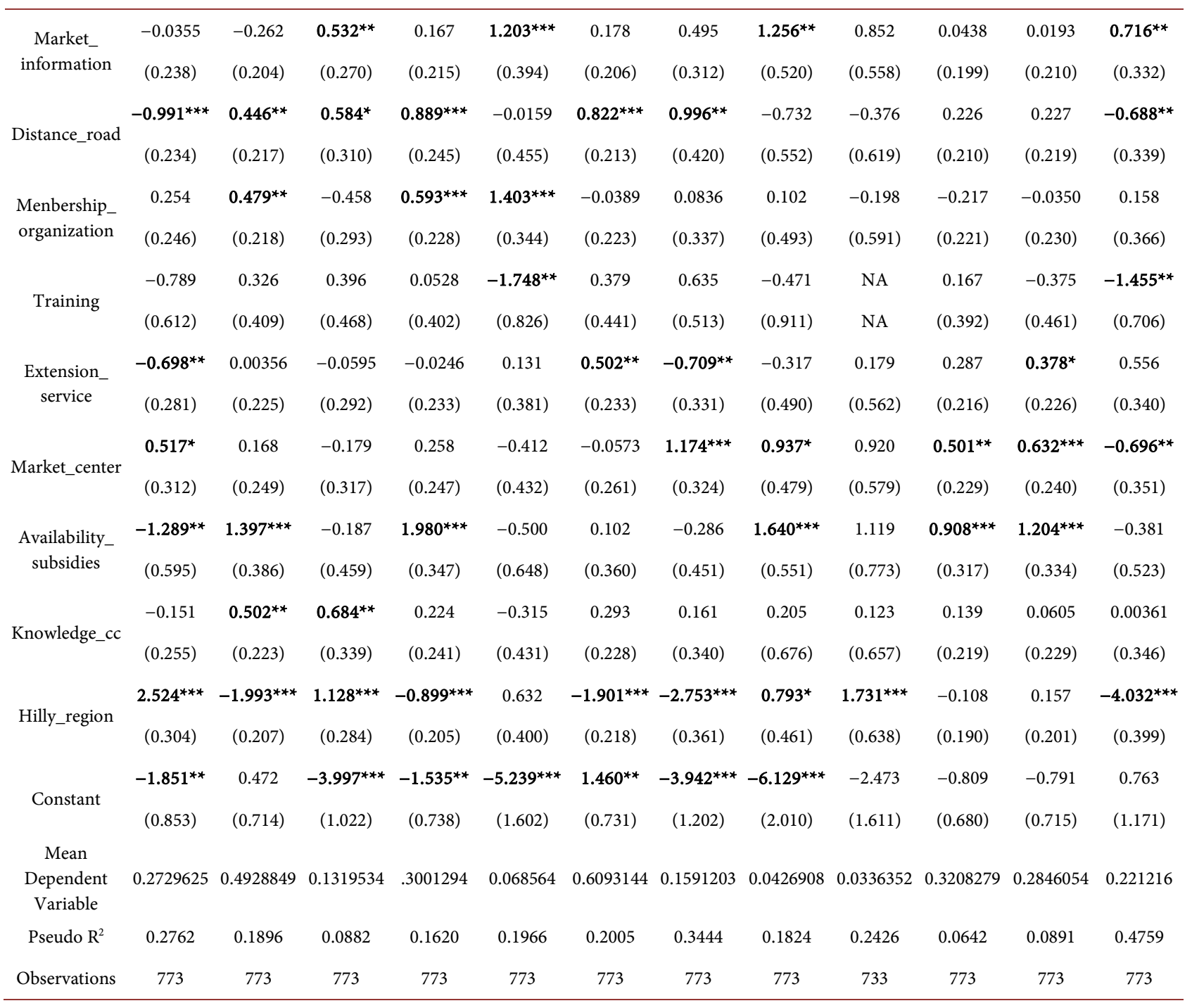

Standard errors are in parentheses. ${ }^{* *} \mathrm{p}<0.01,{ }^{* *} \mathrm{p}<0.05,{ }^{*} \mathrm{p}<0$. 